\title{
Assessment of microbiological quality and nutritional values of a processed edible weevil caterpillar (Rhynchophorus phoenicis) in Port Harcourt, southern Nigeria
}

\author{
W. BRAIDE ${ }^{1 *}$ and R. N. NWAOGUIKPE ${ }^{2}$ \\ ${ }^{I}$ Department of Microbiology, Federal University of Technology, P.M.B 1526, Owerri, Imo State, Nigeria. \\ ${ }^{2}$ Department of Biochemistry, Federal University of Technology, P.M.B 1526, Owerri, Imo State, Nigeria. \\ *Corresponding author: E-mail: wesleybraide2005@yahoo.com; +234-8037100964
}

\begin{abstract}
Investigation into the microbiological quality of processed Rhynchophorus species revealed the presence of bacteria and fungi. Total bacterial and fungal counts were $1.08 \times 10^{5} \mathrm{CFU} / \mathrm{g}$ and $9.2 \times 10^{2} \mathrm{CFU} / \mathrm{g}$ respectively. Bacterial isolates identified included, Lactobacillus plantarum, Staphylococcus aureus, Bacillus subtilis, Pseudomonas aeruginosa and Proteus vulgaris, while the fungal species included Cladosporum sp, Penicillium verrecosum, Aspergilus flavus and Fusarum poae and one species of yeast. Rhynchophorus $\mathrm{sp}$ is rich in protein $(71.63 \%)$, indicating high nutritional quality. The crude fibre $(1.59 \%)$ and ash $(11.97 \%)$ are high and could aid bowel movement and increase mineral contents respectively in the human body. High moisture $(12.14 \%)$ and protein contents could encourage spoilage by proteophilic and hydrophilic bacteria and fungi. Poor sanitation and inadequate storage and marketing conditions may contribute to contamination and recontamination of the products. Intensive education on pre and post-harvest (handling) activities, including proper disposal of intestinal contents, preservation with spices and the application of atmospheric packaging system could reduce contamination with microbes.

(c) 2011 International Formulae Group. All rights reserved.
\end{abstract}

Keywords: Bayelsa suya (Rhynchophorus sp) larvae, nutritional and Microbiological qualities.

\section{INTRODUCTION}

Global demand for food security and safety coupled with increased cases of malnutrition resulting from inadequate and high cost of protein diets, especially in Africa and developing countries necessitated the consumption of insects as a new food alternative that enrich the basic diet of man. The rise in the consumption of insects as food has become inevitable in part of sub-Saharan Africa in particular and Africa in general. Though the use of insects as food had been indigenous to Africa, other continents like Asia, Australia and Latin America have utilized them either as food directly or as food source for many years (Allotey and Mpuchane, 2003).

A large variety of insects including, winged termites, beetles, grubs, ants, locusts, crickets and grasshoppers are edible. These insects are eaten roasted, dried, fried or added to other foods. The larvae of an emperor moth, Imbresia belina are presently the most commonly utilized insects in southern Africa 
(Allotey and Mpuchane, 2003; Gashe et al., 1997). The caterpillar of a lepidopteran, Bunaea alcinoe is edible and is rich in amino acids and proteins (Amadi et al., 2005; Braide et al., 2009; Braide et al., 2010). The Pedi people of southern Africa prefer insects to meat (Quin, 1959), so do the Yukpa people of Venezuela and Colombia prefer traditional insect food to fresh meat (Ruddle, 1973). In Zambia, nutrient analyses of foods consumed by the Bemba revealed $65 \mathrm{~g}$ protein/100 $\mathrm{g}$ of insects for dried caterpillars compared to $32 \mathrm{~g}$ for dried fish, $30 \mathrm{~g}$ for roasted venison and lesser amount for other foods (DeFoliart, 2002).

The rise in the world population has placed greater demand on food security. Insects are abundant and contain useful nutrients like protein, vitamins and minerals (Siame et al., 1996; Motshegwe et al., 1998; Oliviera et al., 1976; Braide et al., 2009; Braide et al., 2010). Africa, a developing continent is facing numerous food problems, and a search for new food alternatives that enrich the basic diet and also supply the traditional African food habits and culture has become inevitable. General studies on the traditional food life style of southern Africa suggest that insects may have supplied a substantial amount of animal protein in their diet (Gelfand, 1971; Quin, 1959). People of the tropical areas of Africa, Asia and Neotropics have utilized the mature larvae of the palm weevil, Rhynchophorus species as food sources for centuries (Allotey \& Mpuchane, 2003).

Presently in Nigeria, numerous edible insects and caterpillar are known, consumed and even preserved, but basic information and data on their proximate composition and microbiological qualities are not sufficient. Oliviera et al. (1976) reported that Rhynchophorus sp found in parts of Nigeria and Zaire is rich in Zinc, protein, thiamine and riboflavin. Wachukwu et al. (2002) had reported on the microorganisms associated with Rhynchophorus phoenicis.
The caterpillars are called "itun" in Yoruba and "Eruru Ngwo" in Igbo all in Nigeria. Rhynchophorus usually breeds inside palm tree under stress and fallen palms (Fasoranti \& Ajiboye, 1993). The method of harvesting, preparation, storage and marketing is unhygienic and susceptible to contamination. During processing the larvae may come in contact with soil and other rotting materials and may become recontaminated by microorganisms that can cause spoilage during drying and storage. It is therefore imperative to determine the sanitary quality of this edible insect.

The study reports on the microbiological quality and the nutritional values of an edible caterpillar of a Rhynchophorus species.

\section{MATERIALS AND METHODS}

Description and sources of sample

Samples of processed Rhynchophorus larvae were bought from hawkers at Rumuokoro Motor Park in Port Harcourt, Rivers State, Nigeria. The sample was identified by Professor B.A.Okwapkpam, an entomologist in the Department of Applied and Environmental Biology, Rivers State University of Science and Technology, Nkpolu, Port Harcourt. Processed Rhynchophorus larvae were sold in sticks in an open market and along major motor parks. Samples were taken immediately to the National Root Crops Research Institute (NRCRI) Laboratory, Umudike, Abia State, Nigeria and stored at $4{ }^{\circ} \mathrm{C}$ prior to analysis.

\section{Preparation of sample for analysis}

Prior to analysis, samples were examined and extraneous materials removed. Samples were divided into two parts, "A" and "B". Part "A" was u sed to determine the proximate composition, while part "B" was used to study the microbiological quality.

Sample "A" was spread out on a laboratory tray and dried in an oven at $65^{\circ} \mathrm{C}$, until a constant weight was obtained. The sample was ground in an Author Thomas 
laboratory mill and sieved through $1 \mathrm{~mm}$ sieve to obtain a powder of the sample used for proximate analysis (AOAC, 2000).

Twenty grams of sample "B" was measured and blended in $180 \mathrm{ml}$ sterile distilled water. One-milliliter portion was aseptically transferred into $9 \mathrm{ml}$ distilled water and serial dilutions continued until a concentration of $10^{-6}$ was obtained.

\section{Determination of microbial counts}

One-tenth milliliter $(0.1 \mathrm{ml})$ of the $4^{\text {th }}$ and $6^{\text {th }}$ dilutions obtained from sample " $\mathrm{B}$ " was aseptically inoculated onto freshly prepared surface-dried potato dextrose agar (PDA) and nutrient agar (NA) plates respectively. Inoculums were spread evenly over the surface of the plate with a sterile hockey stick-like spreader. The experiment was done in triplicate for each medium. PDA culture plates were incubated at room temperature for 5 days, while NA culture plates were incubated at $37{ }^{\circ} \mathrm{C}$ for $48 \mathrm{~h}$. On establishment of growth, the number of bacteria colonies formed on each culture plate was counted using the Gallenkamp electronic colony counter. Fungi counts were obtained with a hand lens. The mean counts from the triplicate plate was obtained and multiplied with the appropriate dilution factor to obtain the total viable cells per unit weight of the sample expressed as the colony forming unit per grams (CFU/g) of the sample (Harrigan and McCance, 1990; ICMSF, 1978; Pelczar and Chan, 1977; Cheesbrough, 2000).

\section{Characterization and identification of isolates}

Visible colonies of bacterial isolates were subjected to colonial characterization described in Cheesbrough (2000); Pelczar et al. (1993) and Pelczar and Chan (1977). Pure cultures of isolates were further characterized by microscopic and biochemical methods (Cheesbrough, 2000; Pelczar et al.., 1993). The identities of the isolate was matched against those is Buchanan and Gibbon (1974).
Cultures of fungi were identified based on macro-and micromorphology, reverse and surface colouration of colonies grown on PDA (Pelczar and Chan, 1977; Harrigan and McCance, 1990; Abbey, 2007). Mycotoxigenic fungi of Aspergillus flavus and Aspergillus parasiticus were distinguished from the other Aspergillus species by a bright orange-yellow reverse colour using A. flavus and $A$. parasiticus medium prepared according to the recipe of Pitt and Hocking (1994) and Pitt et al. (1983). Penicillium species were identified using colony diameters, macro-and micromorphology according to the standardized conditions of Pitt (1979) and Pitt and Hocking (1985). Penicillium species were grown on three different media, namely, Czepak yeast extract agar, malt extract agar and 25\% glycerol nitrate agar for 7 days in the dark at $5{ }^{\circ} \mathrm{C}, 25$ ${ }^{\circ} \mathrm{C}$ and $37{ }^{\circ} \mathrm{C}$ respectively (Pitt and Hocking, 1985; Pitt and Hocking, 1994). Colony diameters were measured after 7 days. Other fungal isolates were matched against those in Barnnet and Hunters (1987).

\section{Determination of proximate composition of sample}

The protein content of the sample was determined by the Kjedahl method adopted by James (1995) and Chang (2003) in which nitrogen content was determined and multiplied by 6.25 . Ash content was determined by the furnace gravimetric method (James, 1995). The soxhlet solvent extraction method of James (1995) was employed in the determination of the fat content. Moisture content was determined by the gravimetric method of A.O.A.C. (2000). The Weenden gravimetric method of Kirk and Sawyer (1998) was used in the determination of crude fiber. Analysis was based on dry matter and expressed in percentage.

\section{RESULTS}

The results obtained from the microbiological analysis of the larvae of 
Rhynchophorus species revealed that both bacteria and fungi were involved in the contamination of the processed samples (Tables 1 and 2). The total bacterial and fungal counts were $1.68 \times 10^{5} \mathrm{CFU} / \mathrm{g}$ and 9.2 $\mathrm{x} 10^{2} \mathrm{CFU} / \mathrm{g}$ respectively. The Tables also revealed the colonial characteristics of the isolates.

The microscopic and biochemical characterization of the bacteria isolated are presented in Tables 3 and 4 respectively, while Table 5 shows the microscopic characteristics of the fungal isolates.

The identities of the bacteria and fungi isolated from the processed larvae are shown in Tables 4 and 5 respectively.

The percentage means value of the total energy and proximate composition of the sample is shown in Tables 6.

Table 1: Total heterotrophic counts and colonial characteristics of bacteria isolated on Nutrient agar.

\begin{tabular}{lcl}
\hline Colony code & $\begin{array}{c}\text { Total counts } \\
(\mathbf{C F U} / \mathbf{g})\end{array}$ & Colonial morphology \\
\hline RNY 1 & & Rough creamy colonies with grey background \\
RNY 2 & & Smooth circular, cream low convex colonies \\
RNY 3 & & Large irregular cream colonies \\
RNY 4 & & Smooth and slimy with green pigment \\
RNY 5 & $\left(1.68 \times 10^{5}\right)$ & Large swarmy colonies \\
\hline
\end{tabular}

Number in parenthesis, total counts of bacteria isolated

Table 2: Total heterotrophic count and colonial characteristics of fungal isolates.

\begin{tabular}{llll}
\hline $\begin{array}{l}\text { Colony } \\
\text { code }\end{array}$ & $\begin{array}{l}\text { Total counts } \\
\text { (CFU/g) }\end{array}$ & Colonial characteristics & $\begin{array}{l}\text { Most probable } \\
\text { identity }\end{array}$ \\
\hline RNY A & & $\begin{array}{l}\text { Tall dark and upright colonies, branched } \\
\text { near the apex in clusters }\end{array}$ & Cladosporum $\mathrm{sp}$ \\
\hline RNY B & $\begin{array}{l}\text { Black-dark brown colonies with visible } \\
\text { tiny spores above the mycelia }\end{array}$ & Aspergillus sp \\
\hline RNY C & $\begin{array}{l}\text { Dark green rough surfaced velvety mass } \\
\text { without clearly visible spores }\end{array}$ & Penicillium sp \\
\hline RNY D & & $\begin{array}{l}\text { Extensive Cotton-like mass of mycelia } \\
\text { growth with slight pigmentation }\end{array}$ & Fusarium $\mathrm{sp}$ \\
\hline RNY E & $\left(9.2 \times 10^{2}\right)$ & $\begin{array}{l}\text { Whitish to cream coloured, round and } \\
\text { butyrous colonies with limited growth }\end{array}$ & $\begin{array}{l}\text { Saccharomyces } \\
\text { sp }\end{array}$ \\
\hline
\end{tabular}


W. BRAIDE et al. / Int. J. Biol. Chem. Sci. 5(2): 410-418, 2011

Table 3: Microscopic characteristics of bacterial isolates.

\begin{tabular}{llllllll}
\hline Colony code & Mot & Gram rnx & Spore & Flagella & Capsule & Cell morphology & Most probable identity \\
\hline RNY 1 & - & + & - & - & - & Long slender rod & Lactobacillus sp \\
RNY 2 & - & + & - & - & - & Oval cells in clusters & Staphylococcus sp \\
RNY 3 & - & + & + & - & - & Large short single rods & Bacillus sp \\
RNY 4 & + & - & - & + & - & Short small single rods & Pseudomonas sp \\
RNY 5 & + & - & - & + & - & Coccal to long filament & Proteus sp \\
\hline
\end{tabular}

Mot, motility; Gram rnx, Gram reaction

Table 4: Biochemical characteristics of bacterial isolates.

\begin{tabular}{|c|c|c|c|c|c|c|c|c|c|c|c|c|c|c|c|c|}
\hline Cat & Oxi & Coag & In & MR & $\mathbf{V P}$ & Cit & $\mathrm{NO}_{3}$ & $\mathrm{H}_{2} \mathrm{~S}$ & Ure & Glu & Suc & $\begin{array}{l}\text { Ma } \\
\text { l }\end{array}$ & Lac & $\begin{array}{l}\text { Man } \\
\text { n }\end{array}$ & Xyl & Identity of isolate \\
\hline- & - & - & - & + & - & - & - & - & - & + & + & - & + & - & + & Lactobacillus plantarum \\
\hline+ & - & + & - & + & - & + & + & - & - & + & + & + & + & + & + & Staphylococcus aureus \\
\hline+ & - & - & - & + & - & + & + & + & - & + & + & + & + & + & + & Bacillus subtilis \\
\hline+ & + & - & - & + & - & + & + & + & - & + & + & + & - & - & - & Pseudomonas aeruginosa \\
\hline+ & - & - & + & + & - & - & + & + & + & + & + & + & - & - & + & Proteus vulgaris \\
\hline
\end{tabular}

, $\mathrm{NO}_{3}$, nitrate reduction; $\mathrm{H}_{2} \mathrm{~S}$, hydrogen sulphite production;

Ure, urease production Glu, glucose; Suc, sucrose; Mal, maltose; Lac, lactose; Mann, mannitol; Xly, xylose 
Table 5: Microscopic characteristics of fungal isolates.

\begin{tabular}{lll}
\hline $\begin{array}{l}\text { Colony } \\
\text { code }\end{array}$ & Cell morphology & Identity of isolates \\
\hline RNY A & $\begin{array}{l}\text { Conidia seen as few cells with varying sizes and shapes. } \\
\text { Conidia borne of short-branched clusters and the } \\
\text { conidiophores had no swelling. }\end{array}$ & Cladosporum sp \\
\hline RNY B & $\begin{array}{l}\text { Simple upright unbranched conidiophores with tappers } \\
\text { developing into an enlarge globase swelling at the apex. } \\
\text { Conidiophore was hyaline and conidia were seen borne on } \\
\text { short chain of sterigma. }\end{array}$ & \\
\hline RNY C & $\begin{array}{l}\text { Upright unbranched conidiophores which are septate } \\
\text { giving a general picture of clustered fingers near the apex. }\end{array}$ & $\begin{array}{l}\text { Penicillium } \\
\text { verrecosum }\end{array}$ \\
& Conidia were seen borne on philiade. & \\
\hline RNY D & $\begin{array}{l}\text { Short slender stocky irregular branched conidiophore. } \\
\text { There appeared to be larger conidia on which smaller ones } \\
\text { were borne. Large conidia were seen as almost boat shaped } \\
\text { and roundish with thickened walls. }\end{array}$ & Fusarium poae \\
\hline RNY E & $\begin{array}{l}\text { Oval cells, with larger cells attached with small round cells } \\
\text { (small buds). }\end{array}$ & $\begin{array}{l}\text { Saccharomyces } \\
\text { cerevisiae }\end{array}$ \\
\hline
\end{tabular}

Table 6: Total energy and proximate composition of Rhynchophorus sp.

\begin{tabular}{llllllll}
\hline Sample & $\begin{array}{l}\text { Total } \\
\text { energy } \\
\text { (Kcal/100 g) }\end{array}$ & Moisture & $\begin{array}{l}\text { Crude } \\
\text { protein }\end{array}$ & Fat & CHO & $\begin{array}{l}\text { Crude } \\
\text { fibre }\end{array}$ & ash \\
\hline RNY & $387.01 \pm 0.9$ & $12.14 \pm 0.1$ & $71.63 \pm 0.7$ & $8.25 \pm 0.03$ & $6.56 \pm 1.0$ & $1.59 \pm 0.2$ & $11.97 \pm 0.4$ \\
\hline$($ Means \pm SD) & & & & & & &
\end{tabular}

\section{DISCUSSION}

The results obtained from the microbiological analysis of the processed Rhynchophorus species indicates the presence of five genera of bacteria: Lactobacillus plantarum, Staphylococcus aureus, Bacillus subtilis, Pseudomonas aeruginosa and Proteus vulgaris, and four genera of moulds, namely, Cladosporum sp, Aspergillus flavus, Penicillium verrucosum and Fusarium poae, as well as one yeast species. The total bacterial count of $1.68 \times 10^{5} \mathrm{CFU} / \mathrm{g}$ suggests contamination and poses health risk following consumption.

Lactobacillus plantarum are effective food spoilage organisms (Harrigan and McCance, 1990). Their presence indicates that the sample is highly susceptible to spoilage resulting from improper handling and processing. The sample is rich in protein and other essential nutrients required for the growth of Lactobacillus plantarum and other organisms involved in food spoilage. Staphylococcus aureus and Bacillus subtilis are ubiquitous and are major food contaminants. They cause food spoilage and usually give rise to food borne illnesses (Nester et al., 1998; Pelczar et al., 1986; Prescott et al., 2002). Staphylococcus aureus cause food intoxication, when allowed to incubate in certain foods and produce heat stable enterotoxins that renders food dangerous even though it appears normal (Prescott et al., 2002). Bacillus subtilis is an endospore former and predominates in soil, and are usually associated with spoilage of 
starchy foods (Prescott et al., 2002; Nesters et al., 1998; Pelczar et al., 1986).

Proteus vulgaris are also food contaminants that act on food with high protein content. They rarely give rise to food borne infections, but generally lower the nutritional quality of contaminated food (Prescott et al., 2002). Pseudomonas aeruginosa are food contaminants with high water activity $\left(\mathrm{a}_{\mathrm{w}}\right)$. They are moist spoilage bacteria characteristic of the processed Rhynohophorus species and are frequently associated with high level food contamination (Harrigan and McCance, 1990; Prescott et al., 2002; Nester et al., 1998). Pseudomonas aeruginosa produce protease and lipases that can catalyze reactions causing degradation of proteins and fats resulting in an undesirable flavour of the food products (Nester et al., 1998).

The fungi species, Cladosporum and Fusarium poae are food contaminants that have rapid growth rates. They cause deterioration and spoilage of stored products. Fusarium poae had been implicated in the production of a potent mycotoxin (Prescott et al., 2002; Frazier and Westhoff, 1978). Some of the isolates are soil borne microorganisms associated with metamorphosing moth larvae (Braide et al., 2008).

The ubiquity and the ability of Aspergillus and Penicillum species to grow at low water activity make them important in post harvest/processed contamination and decay (Blomberg and Alder, 1992; Pitt, 1995). Aspergillus flavus are well known producers of aflatoxins. Aflatoxins whose primary target is the liver are potent carcinogens, mutagens and teratogens and are acutely toxic to animals and human (Siame et al., 1996). Penicillium verrucosum produce citrinin and ochratoxins, and is rated the most important source of ochratoxin in food (Abramson, 1991). Ochratoxin A is a potent nephrotoxin and causes kidney damage in pigs and experimental animals (Pitt and Hocking, 1994; Abramson, 1991).

Results obtained from the proximate analysis showed that the processed larvae of
Rhynchophorus is rich in protein (71.63\%), which indicates high nutritional quality as well as susceptibility to spoilage microorganisms. The presence of crude fibre and ash in high quantity is important as they aid bowel peristalsis and provide minerals to the body respectively (Wardlaw and Kessel, 2002; Delvin, 2006). The moisture content $(12.14 \%)$ is high and is sufficient to encourage the growth and proliferation of food spoilage and disease causing bacteria and fungi.

Poor sanitation may be an important factor in the contamination of processed larvae sold and consumed. The method of collection and utensils used in the preparation together with inadequate storage and marketing may all contribute as sources of contamination. Therefore, use of clean water and utensils, adequate packaging and practice of good sanitary and hygiene within and around the environment could reduce recontamination of the ready-to-eat products.

Preparation of samples with spices containing antimicrobial compounds may discourage bacterial contamination. Spices such as garlic (Allium sativum) and Negro pepper (Xylopia aethiopica) had been reported to contain some antimicrobial compounds (Iwu et al., 1999). Furthermore, lowering the water activity level through curing or drying will reduce the growth of xerophilic and xeroduric organisms.

\section{REFERENCES}

Abbey SD. 2007. Foundation in Medical Mycology ( $4^{\text {th }}$ edn). Kenalf Publication: Port Harcourt, Nigeria; 22-30.

Abramson D. 1991. Development of Moulds, Mycotoxins and odours in moist Cereals during spoilage. In Cereal Grain: Mycotoxins, Fungi and Quality in Drying and Storage, Chelkowski J (ed), Elsevier: London; 119-142.

Allotey J, Mpuchane S. 2003. Utilization of useful insects as food source. African Journal of Food, Agriculture, Nutrition and Development, 3: 1-8. 
Amadi EN, Ogbalu OK, Barimalaa IS, Pius M. 2005. Microbiology and nutritional composition of an edible larva (Bunaea alcinoe. Stoll) of the Niger Delta. Journal of Food Safety, 25: 193-197.

A.O.A.C. 2000. Official Methods of Analysis (17th edn). A.O.A.C. International, Gaithersburg: Maryland, U.S.A.

Barnnet HI, Hunters BB. 1987. Illustrated General of Imperfects Fungi (4th edn). Macmillan Publishing Co.: New York, U.S.A; 106, 130.

Braide W, Sokari TG, Nwaoguikpe RN, Okorondu SI. 2008. Microbes from soils associated with metamorphosing moth larvae. Current Trends in Microbiology, 4: 11 - 14

Braide W, Mbata M, Nwaoguikpe RN, Aniesona AT. 2009. Microbiological and Proximate characteristics of an edible long-winged reproductive termites (Macroterms bellicosus. Smeathman). Journal of Biomedical and Health Development, 2(1): 77-86.

Braide W, Sokari TG, Hart AD. 2010. Nutritional quality of an edible caterpillar of a lepidopteran, Bunaea alcinoe. Advances in Science and Technology, 4: 49-53.

Buchanan RE, Gibbons NE. 1974. Bergey's Manual of Determinative Bacteriology (8th edn). Williams and Wilkins Co.: Baltimore, U.S.A.

Blomberg A, Adler L. 1992. Physiology of osmotolerance in fungi. Adv. Microbiol. Physiol, 33: 145 - 212.

Chang SK. 2003. Protein analysis in Food $\left(3^{\text {rd }}\right.$ edn). Kluwe Academic Plenum Publishers: New York, U.S.A; 134 - 135.

Cheesborough M 2000. District Laboratory Practice in Tropical Countries, Part 2. Cambridge Univ. Press: UK; 35 - 38, 6269.

DeFoliart GR. 2002. The Human Use of Insects as Food Resources: A bibliographic account in progress. Central and Eastern Africa overview.

Delvin TM. 2006. Text Book of Biochemistry with Clinical Correlations (6th edn).
Wiley-Liss. A John Wiley and Son's Inc., Publication: Canada; 743-789.

Fasoranti JO, Ajiboye DO. 1993. Some edible insects of Kwara State, Nigeria. Amer. Entomologist, 39:113-116.

Frazier WF, Westhoff DC. 1978. Food Microbiology (3rd edn). Tata McGrawHill Publishing Co. Limited: New-Delhi, India; 17-64, 454-456.

Gashe BA, Mpuchane SE, Siame BA, Allotey J, Teffera G. 1997. The microbiology of phane, an edible caterpillar of the emperor moth, Imbresia belina. Journal of Food Protection, 60: 1376 - 1380.

Gelfand M. 1971. Diet and Tradition in an African Culture. $\mathrm{E}$ and $\mathrm{S}$ Livingston: Edinburgh, U.K; 44-45.

Harrigan WF, McCance ME. 1990. Laboratory Methods in Food and Dairy Microbiology ( $8^{\text {th }}$ edn). Academic Press Inc.: London; 7-23, 286 - 303.

I.C.M.S.F. 1978. Microorganisms in Foods: Sampling for the Microbiological Analysis. Principles and Specification. Blackwell Publications: New York, USA; 100 - 107, 276- 345.

Iwu MW, Duncan AR, Okunji AN. 1999. New antimicrobial of plant origin, In Perspectives on New Crops and New Uses, Janick J (ed). ASHS Press: Alexandria, VA; 457-462.

James CS. 1995. Analytical Chemistry of Foods. Chapman and Hall: New York, U.S.A; 41-75.

Kirk RS, Sawyer R. 1998. Pearson's Composition and Analysis of Foods $\left(4^{\text {th }}\right.$ edn). Churchill Livingstone: Edinburgh, Britain; 26-28.

Motshegwe SM, Holmback J, Yeboah SO. 1998. General properties and the fatty acid composition of the oil from the mophane caterpillar, Imbresia belina. Journal of American Oil Chemists Society, 75: 725 - 728.

Nester EW, Robert CE, Pearsall NN, Anderson DG, Nester MT. 1998. Microbiology: A Human Perspective, ( $2^{\text {nd }}$ edn), WBC/McGraw-Hill: New York, U.S.A; 415, $434-435$. 
Oliveira JFS, Carvalho SJP, Sousa RFX, Sinao MM. 1976. The nutritional values of four species of insects consumed in Angola. Ecol. Food Nutri., 5: 91-97.

Pelczar CS, Chan EC. 1977. Laboratory Exercise in Microbiology. Black Dot. Inc.: New York, U.S.A; 26-31.

Pelczar MJ (Jr), Chan ECS, Krieg NR. 1986. Microbiology $\quad\left(5^{\text {th }}\right.$ edn). McGraw-Hill Book Co.: New York, USA; 37-50, 133146.

Pelczar MJ (Jr.), Chan ECS, Kreig NR. 1993. Microbiology Concept and Application, ( $1^{\text {st }}$ edn), McGraw-Hill Inc.: New York, U.S.A; 80 - 100, 158 - 161, 370.

Pitt JI. 1979. The Genus Penicillium and its Telemorphic State. Eupenicillium and Talaromyces. Academic Press: London.

Pitt JI, Hocking AD, Glenn DR. 1983. An improved medium for the detection of Aspergillus flavus and Aspergillus parasiticus. Journal Applied. Bacteriology, 54: 109 - 114.

Pitt JI, Hocking AD. 1985. Fungi and Food Spoilage. Academic Press: London.

Pitt JI, Hocking AD. 1994. Modern methods for detecting and enumerating food-borne fungi. In Rapid Analysis Techniques in Food Microbiology, Patel PD (ed). Blackie Academic and Professional: London; 22-28.
Pitt JI. 1995. Phylogeny in the Penicillium: A morphologist's perspective. Can. J. Bot., 73: 768-777.

Prescott MI, Harle JD, Klein DA. 2002. Microbiology of Food ( $5^{\text {th }}$ edn). McGraw Hill Limited: New York, U.S.A; 964 976.

Quin PJ. 1959. Foods and Feeding Habits of the Pedi. Witwatersrand Univ. Press; 278.

Ruddle MS. 1973. Insect Foods as Meat by the Yukpa people. Wide Rang Press; 154.

Siame AB, Mpuchane SE, Gashe BA, Allotey J, Teffera G. 1996. Nutritional Quality of Mophane Worms, Imbresia belina (Westwood), and the Microorganisms Associated with the Worms. Phane Proc. First Multidisp. Symp on Phane; $80-83$.

Wachukwu CK, Thomas CN, Kigigha LT. 2002. Microorganisms associated with palmwine weevil larvae (Rhynchophorus phoenicis. J. Dairying Food and H,S., 21: 44- 47.

Wardlaw GM, Kessel MW. 2002. Perspective in Nutrition ( $5^{\text {th }}$ edn). McGraw Hill Co. Inc.: Boston, USA; 258- 784. 